\title{
Effect of Complex Training on Molecular Differentiation of Skeletal Muscles and Record Level of 100m Hurdles For Female College Students
}

\author{
Shaimaa Naguib ${ }^{1}$, Naglaa Elbadry ${ }^{1}$, Amr Hamza*2 ${ }^{*}$ Adam Zajac $^{3}$, Hussein Abaza $^{4}$, Alin Larion ${ }^{5}$ \\ ${ }^{1}$ Faculty of physical education for girls, Helwan University, Egypt \\ ${ }^{2}$ Faculty of physical education, Aswan University, Egypt
}

${ }^{3}$ The Jerzy Kukuczka Academy of Physical Education in Katowice, Poland

${ }^{4}$ Faculty of physical education, Benha University, Egypt

${ }^{5}$ faculty of physical education, Ovidius University, Romania

*Corresponding author: Amr Hamza, Faculty of physical education, Egypt

\section{ARTICLE INFO}

Received: 慧 February 21, 2019

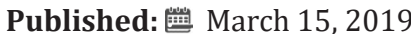

Citation: Shaimaa Naguib, Naglaa Elbadry, Amr hamza, Adam Zajac, Hussein Abaza, Alin L arion. Effect of Complex Training on Molecular Differentiation of Skeletal Muscles and Record Level of 100m Hurdles For Female College Students. Biomed J Sci \& Tech Res 16(1)-2019. BJSTR. MS.ID.002788.

\begin{abstract}
Complex training is a series of exercises performed in succession, one with large loads and another with smaller loads and moved at high speed, with the aim of improving power and speed. The aim of this study is to investigate the impacts of complex training on molecular differentiation of skeletal muscles and record level of $100 \mathrm{~m}$ hurdles for female college students. Ten female college students from Faculty of physical education for girls (grade three). Helwan University participated in this study. All participants were fully informed about the aims of the study and gave their voluntary consent before participation. The measurement procedures were in agreement with ethical human experimentation. The results show very high progress in the completely physical parameters including flexibility, agility, coordination, power of legs, trunk and arms. In addition, the Time of 100-hurdle run was reduced by two seconds, which are very decisive in running time since a fraction of second may change from rank to another.
\end{abstract}

Keywords: Complex Training; Plyometric; MyoD; Protein; Endurance

\section{Introduction}

Strength is a fundamental ability in most sports disciplines. The training carried out for the development of this quality depends on the type of force solicitation that is required in the practiced sports specialty. Players of 100-meter hurdle race require power to overcome the hurdle, which is repeated ten times during the race. In addition, it needs the most explosive power to run the three steps in-between hurdles. Hence, it is important to improve power capacity required to encounter many steps in an explosive muscle contractions for longest time in the race [1]. For each of the manifestations of force, there are various methods of work. One of these methods is complex training. The complex method was developed by Europeans sports scientists to combine training results with heavy loads with what they called "shock training", which is ultimately Plyometrics [2]. As early as 1966, Verkhoshansky recommended the combination of squats and jumps as an interesting method for the development of explosive force [3].
This author defined the complex method as a series of exercises performed in succession, one with large loads and another with smaller loads and moved at high speed, with the aim of improving power and speed [4].

The fundamentals of the complex method are based on the following: work with heavy loads increases the excitability of the moto-neurons and the enhancement reflex, which can create optimum training conditions for the subsequent performance of plyometric exercise [2,4,5]. This phenomenon is known as post-activation potentiation [6]. For this mechanism there are two possible explanations: on the one hand it is thought that it may be due to improvements in the pre-stimulation of motor neurons excitability (greater recruitment of motor units, better synchronization or decrease in presynaptic inhibition) [7-9]. The other possible explanation would be the phosphorylation of the light chain of myosin kinase due to its activation after the release 
of sarcoplasmic calcium because of muscle stimulation. In this way, the ATP is cleaved to form myosin-act bridges. Thus, when accelerated, the sensitivity of phosphorylation of the myosin light chain is increased and, therefore, the rate of formation of these bridges is improved and the muscle fiber increases the rate of development of the force $[6,10]$.

Skeletal muscle is composed of two types of fibers, each of which have its own distinct properties [11]. Type I (slow twitch) muscle fibers that are responsible for oxidative metabolism, rich in mitochondria and are increased in vascularization, hence fatigue resistant. Type II (fast twitch) fibers responsible for glycolytic metabolism and fatigue rapidly [11]. Skeletal muscle can interchange between its fiber types in response to type of exercise training [12]. The basic fiber structure is called basic Helix-LoopHelix (bHLH) is under control of a transcription factor called MyoD [13]. MyoD can control muscle fiber type synthesis [14] and is controlled by many types of complex exercises. MyoD binds DNA as a heterodimer which affecting bHLH proteins synthesis [13]. The $\mathrm{N}$ terminus of MyoD encodes an activation of the histone acetyltransferase and other chromatin remodeling enzymes [15]; direct to fast fibers expression more than slow fibers [16]. Overexpression of an active form of MyoD in muscle results in a slowto-fast fiber type conversion [17]. Thus, this study is an attempt to investigate the impacts of complex training on molecular differentiation of skeletal muscles and record level of $100 \mathrm{~m}$ hurdles for female college students.

\section{Material and Methods}

\section{Experimental Approach to the Problem}

One group (experimental) performed a pre and post training designed intervention in which Power endurance, Flexibility, Agility, Coordination, Leg power, Trunk power, Arm power, Record of 100-meter hurdle and serum MyoD levels. The experimental group trained one hour per day 3 times a week on complex training for ten weeks. The experimental group completed a training program to see whether this type of training modality would have a positive or negative or no effect on study variables. The training design represented in the Table 1.

Table 1: Training program design.

\begin{tabular}{|c|c|c|c|c|c|c|c|}
\hline & \multirow{2}{*}{ Warming } & \multirow{2}{*}{$\begin{array}{l}\text { General Physical } \\
\text { Preparation }\end{array}$} & \multicolumn{3}{|c|}{ Special Physical Preparation } & \multirow{2}{*}{ Skill training } & \multirow{2}{*}{ Cool-Down } \\
\hline & & & Weights & $\begin{array}{l}\text { positive Cool- } \\
\text { Down }\end{array}$ & Plyometric & & \\
\hline Time & $10 \mathrm{~min}$ & $15 \mathrm{~min}$ & $15 \mathrm{~min}$ & $5 \mathrm{~min}$ & $15 \mathrm{~min}$ & $25 \mathrm{~min}$ & $5 \mathrm{~min}$ \\
\hline Aim & $\begin{array}{l}\text { General muscle } \\
\text { warming up }\end{array}$ & $\begin{array}{l}\text { training for agility, } \\
\text { elasticity\& speed, } \\
\text { muscle power }\end{array}$ & \multicolumn{3}{|c|}{$\begin{array}{l}\text { Improving power, power endurance, muscle power for } \\
\text { legs, trunk \& arms. }\end{array}$} & $\begin{array}{c}\text { Improving } 100 \\
\text { hurdles techniques }\end{array}$ & $\begin{array}{l}\text { Return to } \\
\text { normal status }\end{array}$ \\
\hline
\end{tabular}

\section{Participants}

Ten female college students from Faculty of physical education for girls (grade three). Helwan University participated in this study. All participants were fully informed about the aims of the study and gave their voluntary consent before participation. The measurement procedures were in agreement with ethical human experimentation.

\section{Procedures}

Blood Analysis: Rest blood samples were collected under aseptic conditions from the anti-cubital vein. Blood sampling was obtained immediately after effort. The biochemical evaluation of MyoD in serum was measured with a commercial sandwich ELISA assay supplied by life Span Biosciences, Seattle, USA.

Statistical Analysis: All statistical analyses were calculated by the SPSS statistical package. The results are reported as means and Standard Deviations (SD). Student's t-test for Paired samples was used. The level of significance was set at $p \leq 0.05$.

\section{Results}

Table 2 shows the anthropometric characteristics (age, height, weight) of the subjects. No significant differences were observed in anthropometric characteristics. Table 3 shows highly significant increase in all power parameters; power improving was recognized in either the legs or arms and shoulders. Table 4 shows very high progress in the completely physical parameters including flexibility, agility, and coordination, legs, and trunk and arms power. Time of 100 hurdle run was reduced by two seconds which are very decisive in running time since a fraction of second may change from rank to another. Table 5 shows significantly higher post-exercise after the program compared to that obtained post-exercise before the program. Amazing result was designated in the rest where they were very close to each other indicating stability of MyoD levels in serum

Table 2: Anthropometric characteristics of the studied athletes.

\begin{tabular}{|c|c|c|}
\hline Variables & Mean & Skewness \\
\hline Age (years) & $20.4 \pm 0.525$ & 0.48 \\
\hline Height(cm) & $162.7 \pm 6.18$ & 0.68 \\
\hline Weight(kg) & $64.8 \pm 6.01$ & 0.58 \\
\hline
\end{tabular}


Table 3: Power endurance Parameters.

\begin{tabular}{|c|c|c|c|c|c|}
\hline \multicolumn{7}{|c|}{ Leg Power (m) } \\
\hline Mean \pm SD & Before & After & T & P & Significance \\
\hline Right leg jump (20 times) & $26.2 \pm 1.53$ & $28.2 \pm 1.43$ & -6.237 & 0.000 & $\mathrm{~S}$ \\
\hline left leg jump (20 times) & $27.08 \pm 1.32$ & $29.44 \pm 1.98$ & -7.626 & 0.000 & $\mathrm{~S}$ \\
\hline wide jump (30 sec) & $14.97 \pm 0.87$ & $18.09 \pm 0.91$ & -10.104 & 0.000 & $\mathrm{~S}$ \\
\hline \multicolumn{7}{|c|}{ (Arms \& Shoulder power) } \\
\hline Medicine ball (2KG) throw (times/20 sec) & $12.4 \pm 2.63$ & $16.0 \pm 3.59$ & -5.820 & 0.000 & $\mathrm{~S}$ \\
\hline
\end{tabular}

Table 4: Physical parameters.

\begin{tabular}{|c|c|c|c|c|c|}
\hline Mean \pm SD & Before & After & T & P & Significance \\
\hline Flexibility & $19.8 \pm 2.74$ & $24.7 \pm 2.98$ & -6.057 & 0.000 & S \\
\hline Agility & $14.07 \pm 0.94$ & $13.31 \pm 0.93$ & 2.703 & 0.024 & $\mathrm{~S}$ \\
\hline Coordination & $6.19 \pm 0.78$ & $5.29 \pm 0.69$ & 7.997 & 0.000 & $\mathrm{~S}$ \\
\hline Legs ability & $149 \pm 20.79$ & $164.5 \pm 21.01$ & -7.619 & 0.000 & $\mathrm{~S}$ \\
\hline Trunk ability & $4.80 \pm 0.93$ & $6.13 \pm 0.91$ & -5.961 & 0.000 & $\mathrm{~S}$ \\
\hline Arms ability & $5.83 \pm 0.93$ & $7.12 \pm 0.56$ & -6.141 & 0.000 & \\
\hline Record seconds & $24.36 \pm 1.49$ & $22.47 \pm 1.31$ & -4.000 & 0.003 & $\mathrm{~S}$ \\
\hline
\end{tabular}

Table 5: Serum MyoD levels.

\begin{tabular}{|c|c|c|c|c|c|}
\hline Mean \pm SD & Rest & Effort & T & P & 0.000 \\
\hline MyoD Before & $1.09 \pm 0.21$ & $1.93 \pm 0.17$ & -11.738 & 0.000 & S \\
\hline MyoD After & $1.09 \pm 0.11$ & $2.29 \pm 0.28$ & -11.395 & & \\
\hline & Before & After & & 1.00 & NS \\
\hline MyoD Rest & $1.09 \pm 0.21$ & $1.09 \pm 0.11$ & 0.00 & 0.00 & S \\
\hline MyoD Effort & $1.93 \pm 0.17$ & $2.29 \pm 0.28$ & -4.64 & & \\
\hline
\end{tabular}

Note: * The level of significance was set at $\mathrm{p} \leq 0.05$.

\section{Discussion}

The goal of this study was to identify the impacts of complex training on molecular differentiation of skeletal muscles and record level of $100 \mathrm{~m}$ hurdles for female college students. The results indicated that 10 weeks of complex training program can maintain or improve 100 meter hurdle run, physical parameters and MyoD levels in serum between the pre-posttests. This confirmed by anther findings of 12 weeks of complex training program by Kim and Han [18]. Therefore, more-active development and application of this effective and practical complex exercise program are needed. All physical parameters were significantly improved including Flexibility, Agility, Compatibility, Legs ability, Trunk ability, Arms ability and even the $100 \mathrm{M}$ hurdles record in seconds. Previous studies assured different combinations/sequences of weight training combined with plyometric sets result in performance improvements in muscle strength and jump ability [19]. Most agility tasks require a rapid switch from eccentric to concentric muscle action in the leg extensor muscles. Thus, it has been suggested that PLY can decrease ground reaction test times through the increase in muscular force output and movement efficiency, therefore positively affecting agility performance [20]. Also, previous studies investigated the complex training effects on horizontal jump performance when PLY was combined with WT. Results indicated that such combination may be beneficial for enhancing horizontal jumping performance [21].

The main finding of the present study was that power capacity performance was significantly increased after 10 weeks of complex training, with better records of 100-meter hurdle sprints. These results agreed with that suggest performing strength and power training sessions is more effective for improving explosive muscle performance [22]. Stasinaki et al. [22] found that complex training program induce stronger leg power with greater type I muscle fiber cross sectional area. However, studies comparing compound versus complex training indicated load variation in complex training may is the cause to induce power enhancement [23]. Wh (en combined with WT over 6-12 weeks [24,25], sprinting performance improved in the range of $+0.2-3.0 \%$. The resting values of MyoD in all subjects were not significantly changed. In the experimental subjects, there was increased MyoD following exercise whilst in the pre- or postprogram and when compared to control subjects.

Skeletal muscle compensates for the turnover of fibers and cells to maintain tissue homeostasis [26]. This type of myogenesis depends on the activation of satellite cells that can differentiate into new fibers [27]. MyoD is important regulator for adaptation of the skeletal muscle to mechanical stress such as exercise. The activation 
and proliferation of satellite cells is essential for hypertrophy of skeletal muscle. MyoD up-regulate satellite cell proliferation [27]. Previous investigations found MyoD expression was induced 0-8 h after a high glycaemic meal, but only 0 and $3 \mathrm{~h}$ after the same meal plus one-legged knee extensor exercise [28], indicating that MyoD induction time is reduced by the addition of exercise. Induction of MyoD expression by resistance (high load, low repetition) versus endurance (low load, high repetition) exercise has been shown to induce different time courses of MyoD expression. It is increased 8and 5 -fold after 30 min of continuous treadmill running, resistance exercise (consisting of three sets of 10 bilateral knee extensions) on the other hand, enhanced MyoD expression 6-fold $8 \mathrm{~h}$ after the exercise [29-30].

\section{Practical Applications}

Complex Training is a training method aimed at developing high progress in the completely physical parameters including flexibility, agility, coordination, power of legs, trunk and arms. which has a direct effect on the time of 100-hurdle run. When outlining the season planning for athletics, strength and conditioning professionals should take into consideration that this may be a suitable method as it produces high training effects on hurdle sprint performance.

\section{References}

1. El gebaly TE (2015) Recent training system: Theory and application, ( $3^{\text {rd }}$ edn.), Print centre, Cairo, Egypt.

2. Chu DA (1996) Explosive power and strength: complex training for maximum results. Human Kinetics, Champaign, pp. 192.

3. Verkhoshansky Y (1966) Perspectives in the improvement of speedstrength preparation of jumpers. Track and Field 9: 11-12.

4. Fleck SJ, Kontor K (1986) Complex training. National Strength and Conditioning Association Journal 8(5): 66-68.

5. Verkhoshansky Y (1986) Speed-strength preparation and development of strength endurance of athletes in various specializations. Soviet Sports Review 21: 120-124.

6. Sale DG (2002) Postactivation potentiation: Role in human performance. Exercise and Sport Sciences Reviews 30(3): 138-143.

7. Aagaard P (2003) Training induced changes in neural function. Exerc Sport Sci Rev 31(2): 61-67.

8. Gullich A, Schmidtbleicher D (1996) MVC-induced short-term potentiation of explosive force. New Studies in Athletics 11(4): 67-81.

9. Trimble M, Harp S (1998) Postexercise potentiation of the H-reflex in humans. Medicine and Science in Sports and Excercise 30(6): 933-941.

10. Bazett-Jones DM, Winchester JB, McBride JM (2005) Effect of potentiation and stretching on maximal force, rate of force development, and range of motion. J Strength Cond Res 19(2): 421-426.

11. Schiaffino S, Reggiani C (2011) Fiber types inmammalian skeletal muscles. Physiol Rev 91: 1447-1531.

12. Ehlers ML, Celona B, Black BL (2014) NFATc1 controls skeletal muscle fiber type and is a negative regulator of MyoD activity. Cell Rep 8: 16391648.
13. Tapscott SJ (2005) The circuitry of a master switch: Myod and the regulation of skeletal muscle gene transcription. Development 132: 2685-2695.

14. Legerlotz K, Smith H (2008) Role of Myod in denervated, disused, and exercised muscle. Muscle Nerve 38: 1087-1100.

15. Berkes CA, Tapscott SJ (2005) MyoD and the transcriptional control of myogenesis. Semin Cell Dev Biol 16: 585-595.

16. Macharia R, Otto A, Valasek P, Patel K (2010) Neuromuscular junction morphology, fiber-type proportions, and satellite-cell proliferation rates are altered in MyoD(-/-) mice. Muscle Nerve 42: 38-52.

17. Ekmark M, Rana ZA, Stewart G, Hardie DG, Gundersen K (2007) Dephosphorylation of MyoD is linking nerve-evoked activity to fast myosin heavy chain expression in rodent adult skeletal muscle. J Physiol 584: 637-650.

18. Kim S, Han G (2016) Effect of a 12-week complex training on the body composition and cardiorespiratory system of female college students. J Phys Ther Sci 28: 2376-2378.

19. Ronaldo K, Irineu L, Renato B, Saulo G, Rogério C, et al. (2016) Effects of different combinations of strength, power, and plyometric training on the physical performance of elite young soccer players. Journal of Strength \& Conditioning Research, p. 29-38.

20. Polhemus R, Burkhardt E, Osina M (1981) The effects of plyometric training with ankle and vest weights on conventional weight training programs for men and women. NSCA J 3: 13-15.

21. Stasinaki A, Gloumis G, Spengos K, Blazevich A, Zaras N, et al. (2016) Muscle strength, power and morphological adaptations after 6 weeks of compound vs. complex training in healthy men. J Strength Cond Res 29(9): 2559-2569.

22. González Ravé JM, Juárez D, and Navarro F (2009) Effects of complex vs. noncomplex training programs on lower body maximum strength and power. Isokinetics Exerc Sci 17: 233-241.

23. Perez-Gomez J, Olmedillas H, Delgado-Guerra S (2008) Effects of weight lifting training combined with plyometric exercises on physical fitness, body composition, and knee extension velocity during kicking in football. Appl Physiol Nutr Metab 33(3): 501-510.

24. Ronnestad BR, Kvamme NH, Sunde A (2008) Short-term effects of strength and plyometric training on sprint and jump performance in professional soccer players. J Strength Cond Res 22 (3): 773-780.

25. Pellettieri J, Sanchez Alvarado A (2007) Cell turnover and adult tissue homeostasis: From humans to planarians. Annu Rev Genet 41: 83-105.

26. Charge SB, Rudnicki MA (2004) Cellular and molecular regulation of muscle regeneration. Physiol Rev 84: 209-238.

27.Vissing K, Andersen JL and Schjerling P (2005) Are exercise-induced genes induced by exercise? FASEB J 19: 94-96.

28. Yang Y, Creer A, Jemiolo B, Trappe S (2005) Time course of myogenic and metabolic gene expression in response to acute exercise in human skeletal muscle. J Appl Physiol 98: 1745-1752.

29. Young WB, James R, Montgomery I (2002) Is muscle power related to running speed with changes of direction? Journal of Sports Medicine Phys Fitness 42(3): 282-288.

30. Burger T, Boyer-Kendrick T, Dolny D (2000) Complex training compared to a combined weight training and plyometric training program. Journal of Strength and Conditioning Research 14(3): 360. 
ISSN: 2574-1241

DOI: 10.26717/BJSTR.2019.16.002788

Amr Hamza. Biomed J Sci \& Tech Res

CC (P) This work is licensed under Creative

Submission Link: https://biomedres.us/submit-manuscript.php

$\begin{array}{ll}\begin{array}{l}\text { BIOMEDICAL } \\ \text { RESEARCHES }\end{array} & \text { Assets of Publishing with us } \\ \text { - Global archiving of articles } \\ \text { - Immediate, unrestricted online access } \\ \text { - Rigorous Peer Review Process } \\ \text { https://biomedres.us/ }\end{array}$

